\title{
Determinants of E-Learning System Adoption among Ghanaian University Lecturers: An Application of Information System Success \\ and Technology Acceptance Models
}

American Journal of Social Sciences and Humanities

Vol. 5, No. 1, 151-168, 2020

e-ISSN: 2520-5382

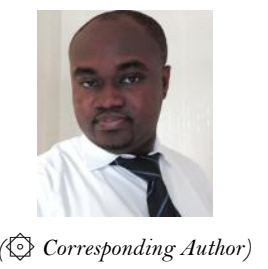

\author{
(D) Daniel Opoku ${ }^{10}$ \\ iD Frederick Pobee ${ }^{2}$ \\ iD Rexford Owusu Okyireh
}

\author{
'School of Business, Human Resource Management Department,University of Education, Winneba, \\ Ghana. \\ Email:dopoku@uew.edu.gh Tel:+233242519893 \\ ${ }^{2}$ Faculty of Business and Economics, University of Pecs, Rakocz, Hungary. \\ Tel: +238245207868 \\ ${ }^{3}$ School of Business, Marketing, Procurement, and Supply Chain Management, University of \\ Education, Winneba, Ghana. \\ Tel: +233244563147
}

\section{ABSTRACT}

This study aims at exploring the factors that influence e-learning adoption among university lecturers. It is realised that the adoption rate of e-learning in the context of developing countries is very low and this has called for more research. A sample size of 131 respondents was selected using both convenience and purposive sampling technique. Questionnaires were used to elicit information from respondents. Data analysis was performed using SPSS and SmartPLS application. The study found eight of the eleven hypotheses tested to be statistically significant whiles the remaining three factors were found to be statistically insignificant. This study is limited to only one university (University of Ghana, Legon). Sakai is a software used by both students and lecturers to facilitate distance learning. So, the concentration of the analysis on just lecturers may not give the clearest picture of the adoption of the software. The results of this study will help developers of an e-learning system to improve users' adoption by critically looking at these factors. Sufficient support and training should also be provided to both administrators and instructors to improve their adoption of rate. This study is one of the first kind to investigate university lecturers' e-learning adoption specifically in a Ghanaian University by applying the Information System Success and Technology Adoption Models. The study, therefore, contributes to the research gap on the lack of e-learning studies in developing countries that have emphasized the use of eLearning systems.

Keywords: E-learning, TAM model, ISS model, Developing country, Technology adoption, Adoption factors, Ghana.

DOI: $10.20448 / 801.51 .151 .168$

Citation | Daniel Opoku; Frederick Pobee; Rexford Owusu Okyireh (2020). Determinants of E-Learning System Adoption among Ghanaian University Lecturers: An Application of Information System Success and Technology Acceptance Models. American Journal of Social Sciences and Humanities, 5(1): 151-168.

Copyright: This work is licensed under a Creative Commons Attribution 3.0 License

Funding: This study received no specific financial support.

Competing Interests: The authors declare that they have no competing interests.

History: Received: 9 October 2019/ Revised: 15 November 2019/ Accepted: 20 December 2019/ Published: 10 February 2020

Publisher: Online Science Publishing 


\section{Highlights of this paper}

- This study aims at exploring the factors that influence e-learning adoption among university lecturers.

- This study is one of the first kind to investigate university lecturers' e-learning adoption specifically in a Ghanaian University by applying the Information System Success and Technology Adoption Models.

- The study, therefore, contributes to the research gap on the lack of e-learning studies in developing countries that have emphasized the use of eLearning systems.

\section{INTRODUCTION}

The rapid growth of the internet and advances in Information technology has caused the enormous implementation of online learning systems in most organizations. Teaching in universities and colleges in Ghana and many developing countries has always followed the classroom methods with lecturers and students having face to face interaction (Gupna et al., 2013). With the recent advancements in ICT and the high penetration rate of the internet, the traditional setup of classroom teaching and learning is changing into an online learning platform, mostly mentioned as "e-learning". The quality of teaching can be enhanced when technology is adopted (Mtebe and Raphael, 2018). E-learning has been recommended and commended by many researchers as a very useful tool for distance education, a way to minimize students or lecturers commuting from their various homes to their institutions (Yakubu and Dasuki, 2018). Selim (2007) defines e-learning as "the use of modern Information and Communications Technology (ICT) and computers to deliver instruction, information, and learning content”. The technology facilitates special capabilities like interactivity, physical mobility and self-directed learning (Bidin and Ziden, 2013). These capabilities have a significant in teaching and learning as it improves the learning ability and also transforms the attitude of users' teamwork (Chen and Tseng, 2012; Ozdamli and Uzunboylu, 2014). However, the quality of teaching in an e-learning environment is greatly affected by the quality of the e-learning systems adopted (Balash et al., 2011; Yakubu and Dasuki, 2018). Some good sides of e-learning is that, first, it lessens the cost attributed to the traditional classroom learning (face to face learning), second, it facilitates coordination and cooperation among participants, third, it helps instructors to track the progress of information delivery (Ruiz et al., 2006; Petit et al., 2013).

Despite the plethora of benefits that accompany e-learning, its adoption is relatively low in developing countries as compared to developed countries. The adoption of technologies in West Africa countries in comparison to other countries in Europe, North America and other developing countries is still in its very early stages (Opoku et al., 2016). Many countries in West Africa are still lagging far behind the developed countries in terms of insufficient knowledge regarding its adoption, usage, implementation, acquisition, and many organizations in these countries are not yet ready to accept the technology (Khasawneh, 2015). Additionally, those the institutions that have adopted e-learning technologies a face many challenges including infrastructure constraints, poor information access, and poor internet connectivity have been reported to be among the factors responsible for low-level adoption in developing countries (Shraim and Khlaif, 2010; Yakubu and Dasuki, 2018). Unlike developing countries, the developed ones have invested resources into their educational system including e-learning, making e-learning a well-established mode of formal education in universities (Yakubu and Dasuki, 2018). A developing country like Ghana is still in her early stages of implementing e-learning in her universities (Boyi, 2014).

E-learning includes both students and instructors, however, it seems most research work conducted tends to focus more on students' perspectives (e.g. (Duan et al., 2010; Freeze et al., 2010; Solangi et al., 2018; Yakubu and Dasuki, 2018)). Research has shown that the acquisition of softwares and hardwares to facilitate e-learning with less support and knowledge will not be profitable to both the students and teachers (Balash et al., 2011). The efficient 
and effective ways to motivate, support and equip lecturers with the skills and competencies to incorporate technological tools in the classrooms are very necessary (Frank et al., 2004; Saade et al., 2007). Nevertheless, if instructors should be trained based on their skills, they can provide reliable, timely, and effective support services to learners who use e-learning systems (Mtebe and Raphael, 2018).

It is envisaged when e-learning adoption rate is high among lecturers, it would cause a greater adoption impact on students. Ghana, with a population about 28 million people, it is estimated that 11 million are internet users, ranking Ghana third in the West African region and eleventh in Africa (World Internet Users' Statistics, 2018). Furthermore, the internet penetration rate in Ghana since the year 2000 till date is $34.3 \%$ (WIUS, 2018). This penetration rate gives room for more technology implementation. For a successful e-learning technology implementation, it is important to identify the factors that contribute towards the adoption of e-learning by university lecturers. The literature has been quite silent with just a little having carried out studies to explore the factors responsible for lecturer's adoption of e-learning (Balash et al., 2011; Khasawneh, 2015; Yakubu and Dasuki, 2018) and this perhaps is a result of inadequate facilities and resources in most universities to implement and use this technology. Yakubu and Dasuki (2018) who conducted a study among Nigerian university students recommended that researchers should explore more on instructors technology adoptions since there is a paucity of research in that area. This study, therefore, attempts to fill a research gap by investigating the factors influencing elearning adoption by university lecturers in Ghana. The e-learning platform under investigation in this study is known as Sakai Management System (Sakai LMS). Sakai LMS is used by university lecturers to organize courses, assignments, class assessment, facilitate discussion forum, organizing students' interim assessment and plagiarism checks. The study integrated some factors of the Technology Adoption Model (TAM) and the Information System Success (ISS) model to understand e-learning adoption. The findings from this study will contribute to literature and knowledge by providing empirical evidence explaining the factors responsible for the successful adoption and usage of Sakai LMS by lecturers of a Ghanaian University.

\section{LITERATURE REVIEW}

Prior attempts to define information systems (IS) success fell short due to the complex of IS success. DeLone and McLean (1992) in an attempt to respond to this problem presented a Success Model that has been used and keeps evolving in the field of IS. The IS success model presented by DeLone and McLean (1992) was updated in 2003 and the model holds that information quality, service quality, systems quality, intention to use/use, user satisfaction and net benefit are the six components of IS success. Concerning the IS success model, system use precedes user satisfaction while positive experience with use enhances satisfaction leading to greater intention to use (Petter et al., 2008). Some research studies have augmented IS model with other technology adoption frameworks. For instance, Li et al. (2012) recognized that e-learning determinants such as service quality, perceived usefulness, course quality, perceived ease of use and self-efficacy directly affect e-learning systems use, whereas, the functionality features of the system and the response user get from the system indirectly affect e-learning systems use. Yakubu and Dasuki (2018) conducted a study on e-learning adoption among university students in Nigeria with a newly proposed model of the IS success model. The authors added behavioural intention and actual usage to some constructs of the IS Success model to study user e-learning adoption.

Cheng (2012) examined the effect of quality e-learning on the intention to adopt and use, in doing so, he incorporated instructor quality to the already theorized factors of IS success model and emphasized that information, service, system, and instructor quality have a positive significant effect on e-learning. Likewise, Jagannathan et al. (2018) employed the model by adding security as a construct in a study to examine the acceptance 
of internet banking adoption. Freeze et al. (2010) also explored IS Success Model in E-Learning Context-Based by adding system success in studying Students' Perceptions. Hsu et al. (2014) extended the model by adding the trust variable in the context of e-commerce. Lee-Post (2009) also evaluated the e-Learning Success Model in an Information Systems Perspective. Mtebe and Raphael (2018) looked at key factors in learners' satisfaction with the e-learning system at the University of Dares Salaam, Tanzania, by incorporating constructs like instructor quality and perceived usefulness. Some other scholars have also validated the model in studies like eGovernment systems (Wang and Liao, 2008) e-commerce (Delone and Mclean, 2004) and a mandatory information system (Iivari, 2005). Some studies have also come out with association among constructs. For instance, Wang and Chiu (2011) incorporated communication quality to the other components of the IS success model. The authors showed that communication quality, service quality and information quality have a positive significant effect on the degree to which users get satisfied. However, when users are satisfied, it results in an intention to reuse the e-learning systems for various learning activities like interactions and getting feedbacks. Al-Harbi (2011) investigated the factors that influence e-learning by analyzing the perceptions and attitudes of Saudi university students. Al-Harbi (2011) in his study combined factors from TAM and TPB to explain significant perceptional and attitudinal factors related to the acceptance of e-learning (Davis, 1989; Ajzen, 1991). The findings demonstrated that attitudes toward e-learning, subjective norms, perceived behavioural control, as well as e-learning system attributes, were critical determinants of students' behavioural intention to use e-learning. A study by Cheng (2012) used constructs from the technology acceptance model (TAM) by Davis (1989) and the updated Information System Success model by Delone and McLean (2003) to examine the effect of quality antecedents on learners' intention to use an eLearning system. In the study, the author found system quality, information quality and service as significant predictors of user satisfaction. This result differs from Lwoga (2014) who showed that information quality and service quality had no relationship with user satisfaction. According to Alsabawy et al. (2013) IT services are important for elearning to be successful as they can positively influence perceived usefulness, and user satisfaction. On the other hand, Sawang et al. (2013) argue that even in the absence of a high-quality IT service, a good e-learning support system can compensate for the low technological efficacy. Gupna et al. (2013) opined that the quality of teaching in an e-learning environment is greatly affected by the quality of the e-learning systems adopted.

\section{RESEARCH FRAMEWORK AND HYPOTHESES}

The study adopted the DeLone and McLean IS success model (D\&M) (Delone and McLean, 2003) and the Technology acceptance model (TAM) (Davis et al., 1992) to explore e-learning adoption from an academic faculty perspective, specifically; lecturers. The two research frameworks were integrated to improve the understanding of e-learning adoption within a developing country context like Ghana. The technology adoption model (TAM) has been seen as a very powerful model that helps to understand individual technology adoption. TAM has been used in a wide range of studies, including $3 \mathrm{G}$ adoption service (Chong et al., 2012; Opoku and Adu, 2016) mobile commerce (Yang, 2005; Kim et al., 2007; Alalwan et al., 2018) E-banking (Kolodinsky et al., 2004; Hassan et al., 2018) Elearning (Gamble, 2017; Tan and Hsu, 2018) cloud computing (Oliveira et al., 2014; Gangwar et al., 2015; Sharma et al., 2016) etc. The TAM model intends to explain users' behavioural intention to use any information technology. According to Davis (1989) TAM proposed that two primary factors, namely; perceived ease of use and perceived usefulness, are able to determine users' intentions to accept or reject a new information technology (Chong et al., 2012). Perceived usefulness is the degree to which a person believes that using a particular system would be beneficial to him or her, while perceived ease of use is the degree to which a person believes that using a particular information technology would be free of effort (Davis, 1989). However, the construct perceived ease of use, in turn, 
will influence the perceived usefulness of the information technology (Dzandu et al., 2016). The TAM has received considerable support over the years. It has been validated over a wide range of systems, and perceived usefulness and perceived ease of use have proven to be reliable and valid cognitive dimensions (King and He, 2006; Chong et al., 2012; Gamble, 2017). Generally, most researchers have seen TAM explain between 30\% and 40\% of individuals' system usage (Burton-Jones and Hubona, 2006; Opoku and Adu, 2016). Further, perceived usefulness is often found to be the strongest determinant in the model (McFarland and Hamilton, 2006; Dzandu et al., 2016). It is therefore very important to consider these factors when investigating users' intention to use e-learning. Although there are several studies on e-learning adoption with different combinations of theories and models, very few studies have combined TAM and IS model (e.g. (Cheng, 2012; Mtebe and Raphael, 2018; Yakubu and Dasuki, 2018)). The inclusiveness, validity and reliability of the TAM and IS Success model in different studies have encouraged this study to adopt and validate it in the context of e-learning adoption among university lecturers in a developing country. Following this and owing to the rarity of research in e-learning adoption, this study steps in to investigate the factors influencing e-learning adoption among university lecturers in Ghana. In this study, the updated D \& M model was modified by including perceived usefulness and actual system usage as new factors relevant in e-learning contexts. The new proposed model consists of seven factors: system quality, service quality, information quality, perceived usefulness, lecturers' satisfaction, intention to use and actual usage. However, perceived ease of use is seen as a feature used to measure system quality (Petter et al., 2008). Due to this, it was not used as a standalone construct. The proposed research model is shown in Figure 1, followed by the description of each factor and hypothesis.

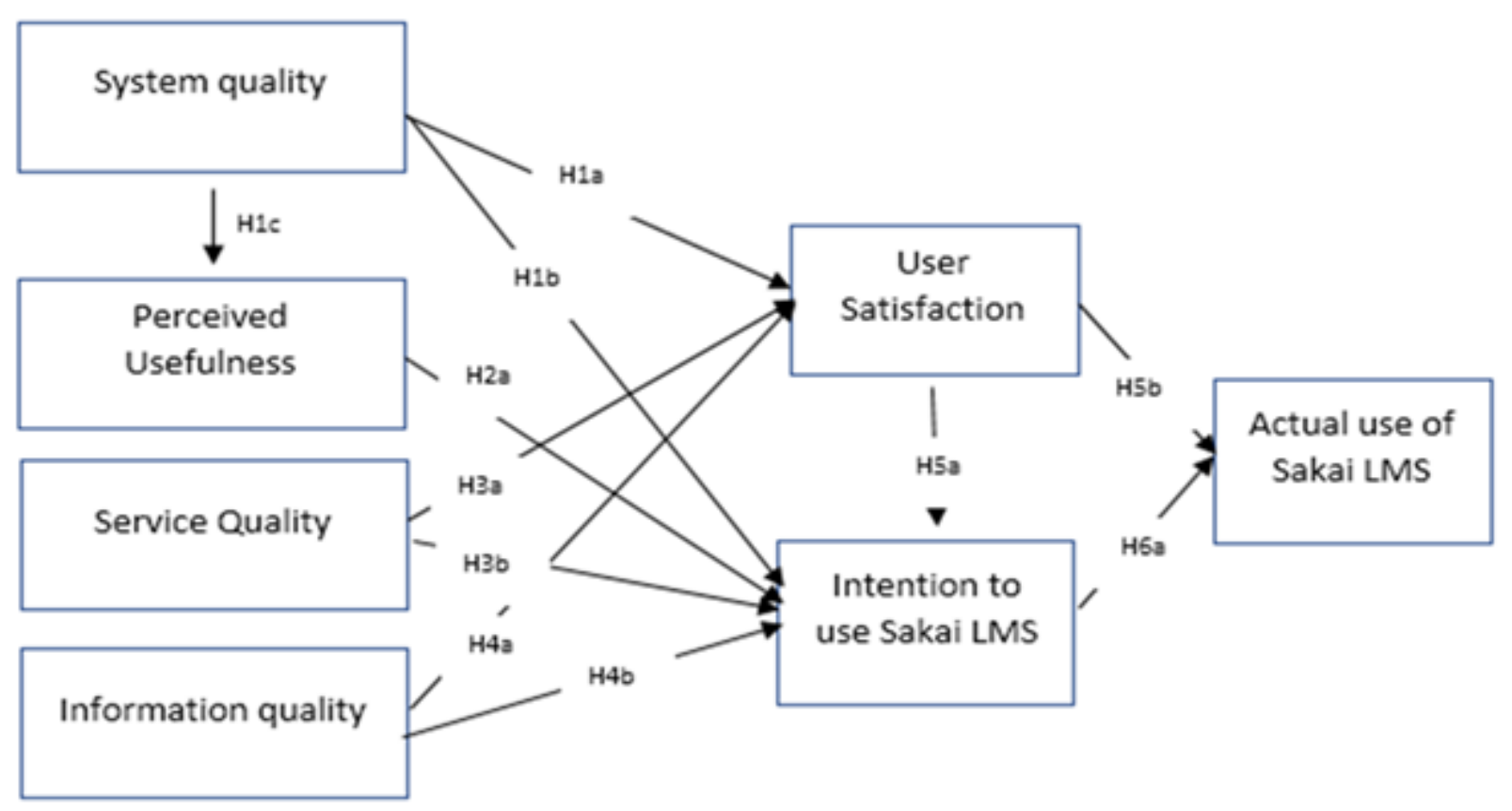

Figure-1. Research framework.

\subsection{System Quality}

System quality is the required features of an IS system according to Petter et al. (2008). When Delone and McLean (2003) proposed the IS success model they referred to systems quality as the accuracy the system that produces information. When a system has too many bugs, its accuracy will be limited (Seddon and Kiew, 1996) and it may reduce the satisfaction level of users (Mtebe and Raphael, 2018). Studies on e-learning have shown that quality of a system has a significant positive effect on user satisfaction (Acton et al., 2009; Wang and Chiu, 2011; 
Saba, 2013) and their intention to use e-learning (Ramayah et al., 2010; Wang and Chiu, 2011; Cheng, 2012; Islam, 2012; Li et al., 2012). Therefore, if the system is easy to use, instructors are likely to use it more frequently, which may lead to having a positive impact on their satisfaction. Also, if the system is very easy to use and can increase staff work performance, it is likely to influence their perceived usefulness (Cheng et al., 2012). Therefore, we hypothesize that;

H1 a: System quality will have a positive influence on lecturers' satisfaction with Sakai LMS.

H1b: System quality will have a positive influence on the intention to use Sakai LMS.

H1c: System quality will have a positive influence on perceived usefulness with Sakai LMS

\subsection{Perceived Usefulness (PU)}

PU refers to the degree to which an individual believes that using a system would enhance his or her job performance (Davis, 1989). Perceived benefits of a system are one key determinant that influences its use. Studies like; Chen and Tseng (2012); Cheng et al. (2012); Chow et al. (2012); Li et al. (2012) found PU to have a positive correlation on use intention for e-learning. Concerning using Sakai LMS, lecturers can organize quizzes and assignments online without necessarily going through the paper-based method. If they can understand how the system works and its benefits, it is likely to increase their work performance. The higher the perceived benefits of e-learning, the greater its intention to use. Hence;

H2a. Perceived usefulness will have a positive influence on the intention to use Sakai LMS

\subsection{Service Quality (Ser_Q)}

Delone and McLean (2003) defined service quality as "the quality of support services that users receive from the IT department or IT support personnel". In the context of e-learning, service quality can be seen as the necessary supports given to e-learning users. This could be network support, system update support and as well as hardware support (Yakubu and Dasuki, 2018). According to Petter et al. (2008) service quality is the assistance and support users of e-learning systems receive from IS systems. It is also concerned if the system has bugs. Studies have found service quality to have a significant positive effect on satisfaction in e-learning (Wang and Chiu, 2011; Tajuddin et al., 2013; Poulova and Simonova, 2014; Xu et al., 2014) and on intention to use e-learning (Ramayah et al., 2010; Wang and Chiu, 2011; Cheng, 2012; Hassanzadeh et al., 2012; Li et al., 2012; Mtebe and Raphael, 2018). Therefore, it is very imperative to include service quality as one of the factors that could affect e-learning adoption. Therefore, we hypothesize that;

H3a. Service quality will have a positive influence on lecturers' satisfaction with Sakai LMS.

H3b. Service quality will have a positive influence on the intention to use Sakai LMS.

\subsection{Information Quality}

Information quality refers to the required characteristics of e-learning output (Petter et al., 2008). This refers to how successful the content of the e-learning is to the user. However, some attributes of the system should include timeliness, easy to comprehend, availability, relevance, completeness, and as well as security. Preceding studies have shown that information quality has a positive influence on user satisfaction (Roca et al., 2006; Hassanzadeh et al., 2012; Kim et al., 2012; Saba, 2013) and intention to use e-learning (Ramayah et al., 2010; Wang and Chiu, 2011; Cheng, 2012). Following from this, the study hypothesizes that;

H4a. Information quality will have a positive influence on lecturers' satisfaction with Sakai LMS.

H4b. Information quality will have a positive influence on the intention to use Sakai LMS. 


\subsection{Lecturers' Satisfaction}

Satisfaction refers to the extent to which an individual believes that his/her needs, goal, and desires have been fully met (Sanchez-Franco, 2009). Within the IS context, satisfaction is the degree to which IS users are delighted with IS and its support systems (Petter et al., 2008). The revised IS model by Delone and McLean (2003) puts user satisfaction after systems use. Therefore, the greater the satisfaction, the greater the intention to use e-learning systems and eventually the actual use (Petter et al., 2008). Some studies have revealed that satisfaction has a positive correlation with the intention to use e-learning (Ruiz et al., 2006; Petter et al., 2008; Udo et al., 2011 ; Hassanzadeh et al., 2012; Islam, 2012). Hassanzadeh et al. (2012) also revealed a positive correlation between satisfaction and actual use of e-learning. Consequently, the study hypothesizes;

H5a. Lecturers' satisfaction of using Sakai LMS will positively affect intention to use.

H5b. Lecturers' satisfaction of using Sakai LMS will positively affect actual usage.

\subsection{Intention to Use}

User intention is a key assurance that an individual will use a technology/system (Schierz et al., 2010) or engage in a particular behaviour. In the updated model of D\&M IS success model, all the constructs (factors) were considered to influence intention to use e-learning system. In the context of e-learning, several studies have support for the relationship between intention to use and actual usage of e-learning system (Alkhalaf et al., 2012; Chow et al., 2012; Hassanzadeh et al., 2012). The dimension of users' intention includes the intention and predicted use of elearning. Hence, if the user has the intention to use a system it is likely to affect his or her actual usage.

H6a. Intention to use Sakai LMS will positively affect actual usage.

\subsection{Actual Usage}

The actual usage or system usage measures the activities or actions of an individual using a particular technology; specifically, e-learning system. According to Venkatesh et al. (2003) in the Unified Theory of Acceptance and Use of Technology (UTAUT), the behavioural intention of an individual lead to the actual behaviour or actual system usage. Similarly, the updated DeLone and McLean (1992) ISS model postulates that the behavioural intention of an individual will also lead to the actual behaviour. Mohammadi (2015) has verified this in their studies on e-Learning systems. Other studies by Chong et al. (2012) and Suki (2011) have also validated this in some studies. Lecturers' perceive actual usage in terms of whether the e-learning system adds value or do not add value to their teaching experience. However, if the lecturer finds the usage as adding value to in terms of their work performance, it will then perceived as successful.

\section{RESEARCH METHODOLOGY}

The study aims to investigate the factors responsible for the use of an e-learning system called Sakai LMS by university lecturers (University of Ghana, Legon). Sakai LMS allows lecturers to mount their courses at the beginning of the semester, upload course materials for students and organize online quizzes and tests for students. This application allows students to participate in group discussions, submit assignments and as well as to communicate with their lecturers. A survey research design was employed in the study. The choice of this design is to generate quantitative descriptions of the characteristic of the respondents and test the relationship among the constructs (factors) used. The respondents of the study were university lecturers from Ghana. This decision was made because the university lecturers were found to be technology savvy and they are likely to use any technological tool to enhance their teaching. Purposive sampling technique was used to select lecturers using Sakai 
LMS. Out of 160 questionnaires sent through online, 131 were received and used for analysis. The survey questionnaire was in threefold. The first part seeks consent from the respondents to assure them of confidentiality. The second part focused on demographic information and the last part contains statements regarding the conceptual framework used for the study. Five points Likert scale was employed to show the extent to which the respondents agreed or disagree with the statements used to measure the constructs. The items measuring service quality, system quality, information quality and user satisfaction were adapted from the updated model of D \&M (DeLone and McLean, 1992) whiles intention to use, perceived usefulness and actual usage were adapted from TAM (Davis, 1989). The study data was analyzed using both SPSS and SmartPLS application. The study tested the hypothesis, checked for the reliability and as well as the validity of the measurement model. The items used for the study were drafted to suit the context of the study. In all, a total number of 32 items were used for the analysis

\section{DATA ANALYSIS AND RESULTS}

\subsection{Demographic Profile}

The participants of the study were profiled according to their gender, age, college, rank and length of service. The results show that out of 131 responses, $64.1 \%$ (84) were females, and the remaining $35.9 \%$ (47) were males. Also, the majority of the participants, 39.5\% (52) were within the ages of 50-59 years. Those within the ages of 4049 years accounted for $23.7 \%$, while those within the ages of $30-39$ years constituted $14.5 \%$. Similarly, those within the ages of 60-69 years constituted 13.7\% (18) whilst those between 20-29 years accounted for $8.4 \%$ (11). The study further revealed that majority 39.7\% (52) of the respondents were from the College of Humanities; followed by those from the College of Health Science (30.5\%), Basic and Applied Science (26.0\%) and Education (3.8\%). The study also analyzed the ranks of the respondents. It was noticed that $33.6 \%$ (44) of them were senior lecturers which constitute the majority of the respondents. $24.4 \%$ (32) were found to be lecturers, followed by assistant lecturers, Professor and Associate Professor Representing 16.0\%, 13.7\% and 12.2\% respectively.

\subsection{Instrument Validity and Reliability \\ 5.2.1. Reliability of Variables}

The study tested the reliability of the factors. This was done to remove items that may not contribute significantly to the study. Three types of reliability test were employed. The first was to perform indicator reliability (outer loading consistency). This was done to find out the strength of each item and how they contribute to their respective factors. This was done by squaring each of the outer loadings (items) and comparing the values obtained to a much acceptable level for indicator reliability. According to Hair et al. (2012) the threshold for indicator reliability should be valued larger than the minimum acceptable level of 0.4. Values above 0.6 were considered as the threshold for the study. However, two of the items (SQ6, SQ7) were dropped due to its weak factor loadings $(\mathrm{SQ} 6=-0.662, \mathrm{SQ} 7=0.152)$. The model was then tested again after removing the items to obtain a new measurement scale. The study also used both composite and Cronbach alpha reliability to check for the internal consistency (reliability) of the items (inner loadings). As per Hair et al. (2014) the combination of each item representing a particular construct or factor should have a reliability value of 0.7. Values above this figure are considered as reliable although other studies warrant to use values, including O.6 (Bagozzi and Yi, 1988; Hair et al., 2013). As presented in Table 1 , it is seen that all the constructs have reliability values more than 0.7 , using both Cronbach alpha and composite reliability, hence the constructs as said to be reliable. 


\subsection{Construct Validity}

\subsubsection{Convergent}

Convergent and discriminant validity were used to verify the validity of the constructs. This validity makes researchers understand that items related to a particular construct should relate to or measure that construct. That is, there should be a high proportion of variance in building items (Hair et al., 2012). The Average Variance Extracted (AVE) of each latent variable is evaluated to check convergent validity. For validity, AVE should be above the recommended cut - off of 0.50 for each construct (Bagozzi and Yi, 1988). From Table 2, all AVE values were found to be higher than the acceptable threshold of 0.5 , this indicates that the construct items relate to each other, thus confirming convergent validity.

Table-1. Construct reliability.

\begin{tabular}{|c|c|c|c|c|c|}
\hline Factor/Construct & $\begin{array}{l}\text { Indicator } \\
\text { (items) }\end{array}$ & loadings & $\begin{array}{c}\text { Indicator } \\
\text { Reliability (i.e.loadings2) }\end{array}$ & $\begin{array}{l}\text { Cronbach's } \\
\text { alpha }\end{array}$ & $\begin{array}{l}\text { Composite } \\
\text { Reliability }\end{array}$ \\
\hline \multirow{5}{*}{$\begin{array}{l}\text { System Quality } \\
\text { (SQ) }\end{array}$} & $\mathrm{SQ}_{1}$ & 0.876 & 0.7673 & \multirow[t]{5}{*}{0.919} & \multirow[t]{5}{*}{0.939} \\
\hline & $\mathrm{SQ}^{2}$ & 0.907 & 0.8226 & & \\
\hline & SQ3 & 0.867 & 0.7516 & & \\
\hline & $\mathrm{SQ}_{4}$ & 0.873 & 0.7621 & & \\
\hline & SQ5 & 0.823 & 0.6773 & & \\
\hline \multirow{6}{*}{$\begin{array}{l}\text { Perceived Usefulness } \\
(\mathrm{PU})\end{array}$} & PU1 & 0.879 & 0.7726 & \multirow[t]{6}{*}{0.939} & \multirow[t]{6}{*}{0.952} \\
\hline & PU2 & 0.876 & 0.7673 & & \\
\hline & PU3 & 0.919 & 0.8445 & & \\
\hline & PU4 & 0.932 & 0.8686 & & \\
\hline & PU5 & 0.778 & 0.6053 & & \\
\hline & PU6 & 0.868 & 0.7534 & & \\
\hline \multirow{6}{*}{$\begin{array}{l}\text { Service Quality } \\
(\text { Ser_Q) }\end{array}$} & SSQ1 & 0.902 & 0.8136 & \multirow[t]{6}{*}{0.944} & \multirow[t]{6}{*}{0.956} \\
\hline & $\mathrm{SSQ}^{2}$ & 0.917 & 0.8408 & & \\
\hline & $\mathrm{SSQ} 3$ & 0.799 & 0.6384 & & \\
\hline & $\mathrm{SSQ}_{4}$ & 0.909 & 0.8262 & & \\
\hline & $\mathrm{SSQ} 5$ & 0.870 & 0.7569 & & \\
\hline & SSQ6 & 0.904 & 0.8172 & & \\
\hline \multirow[t]{3}{*}{ Information Quality (IQ) } & $\mathrm{IQ}_{1}$ & 0.859 & 0.7378 & \multirow[t]{3}{*}{0.836} & \multirow[t]{3}{*}{0.895} \\
\hline & $\mathrm{IQ}^{2}$ & 0.872 & 0.7603 & & \\
\hline & IQ3 & 0.850 & 0.7225 & & \\
\hline \multirow[t]{3}{*}{ Intention Use (IU) } & BI 1 & 0.916 & 0.8408 & \multirow[t]{3}{*}{0.893} & \multirow[t]{3}{*}{0.933} \\
\hline & $\mathrm{BI} 2$ & 0.903 & 0.8154 & & \\
\hline & B13 & 0.904 & 0.8172 & & \\
\hline \multirow{3}{*}{$\begin{array}{l}\text { Lecturers Satisfaction } \\
\text { (LS) }\end{array}$} & $\mathrm{LS}_{1}$ & 0.893 & 0.7974 & \multirow[t]{3}{*}{0.909} & \multirow[t]{3}{*}{0.943} \\
\hline & $\mathrm{LS} 2$ & 0.935 & 0.8742 & & \\
\hline & LS3 & 0.931 & 0.8649 & & \\
\hline \multirow{4}{*}{$\begin{array}{l}\text { Actual Usage } \\
(\mathrm{AU})\end{array}$} & ACT 1 & 0.912 & 0.8317 & \multirow[t]{4}{*}{0.921} & \multirow[t]{4}{*}{0.944} \\
\hline & $\mathrm{ACT} 2$ & 0.905 & 0.8190 & & \\
\hline & ACT3 & 0.853 & 0.7276 & & \\
\hline & $\mathrm{ACT} 4$ & 0.924 & 0.8537 & & \\
\hline
\end{tabular}

\subsubsection{Discriminant}

Discriminant validity, which has also been evaluated, "reflects the degree to which any single construct is unique and not merely a reflection of other variables" (Hulland, 1999). Discriminant validity is obtained by computing the square root of AVE to determine whether the values between the latent variables are larger than other correlation values (Fornell and Larcker, 1981). To obtain values for discriminate validity, a table is constructed in which the square root of AVE is manually calculated and written in bold on the diagonal of a correlation table between the constructs as shown in Table 3. The Service Quality AVE is found to be 0.783, from Table 3, so its square root becomes 0.844 . This number exceeds the correlation values in the service quality column $(0.709,0.515,0.685,0.594$ and 0.671$)$ and also exceeds those in the service quality row (0.602). A similar 
observation is also made for the constructs; perceived usefulness, system quality, quality of information, intention to use, the satisfaction of lecturers and actual use of the system. These results indicate a well - established discriminate validity

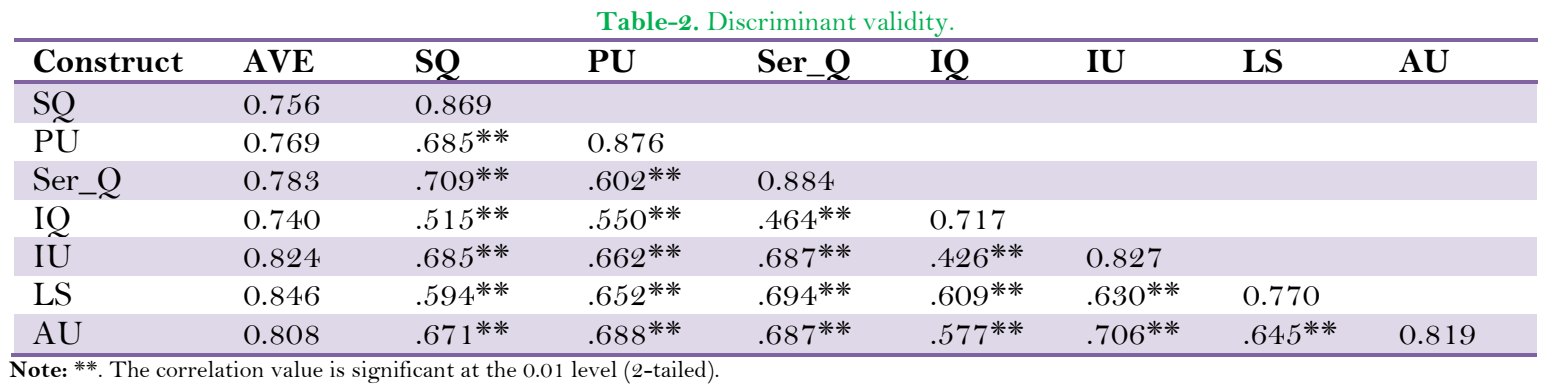

\subsection{Hypothesis Testing and Structural Model Assessment}

The study tested for both the significance of the model and the various hypotheses set up for the study employing a Bootstrapping method usually found in SmartPLS. The results obtained from the bootstrap methods usually approximate the normality of data (Hair et al., 2013; Pobee and Opoku, 2018). The hypothesis with T-values greater than the recommended cutoff value of 1.96 is considered as significant. It was found that system quality explains $47.3 \%$ of the variability in perceived usefulness. Further, system quality, service quality and information quality were also found to explain $61.6 \%$ of the variance in lecturer's satisfaction. System quality, service quality, information quality and perceived usefulness explained $61 \%$ of the variance in lecturer's intention to use Sakai LMS. Finally, lecturer's satisfaction and their intention to use Sakai LMS explains $57 \%$ of the variance in their actual usage.

The path coefficients in Table 3 show that 8 (eight) were statistically significant and supports the relationships among the variables. That is, hypotheses H1b, H1c, H2a, H3a, H3b, H4a, H5a and H6a. However, there were no supports for H1a, H4b and H5b. System quality was found non-significant in its relationship to influence lecturers' satisfaction $(\beta=0.078, \mathrm{P}<0.078)$. However, it was statistically significant to intention to use and perceived usefulness. Also, hypothesis H2a (perceived usefulness and intention to use) was positive and significant $(\beta=0.248$, $\mathrm{P}<0.008)$. This indicates that perceived usefulness has a significant influence on lecturers' intention to use Sakai LMS. Hypothesis H3a and H3b of the relationship between service quality and lecturers' satisfaction; and service quality and lecturers' intention to use Sakai LMS were found to be positive and significant with $\beta=0.429, \mathrm{P}=$ 0.000 ; and $\beta=0.277, \mathrm{P}=0.003$ respectively. Hypothesis H4a (information quality and lecturers' satisfaction) was positive and significant $(\beta=0.403, \mathrm{P}=0.000)$. This indicates that information quality has a significant influence on lecturers' satisfaction. On the other hand, H4b (information quality and Intention to use) was found to be statistically insignificant $(\beta=-0.048, \mathrm{P}=0.561)$. This indicates that although users of Sakai LMS feels that the kind of information the system provides may give them some kind of satisfaction, it does not necessarily mean it will influence their intention to use. Hypothesis H5a (Lecturers' satisfaction and actual usage of the system) was positive and significant $(\beta=0.332, \mathrm{P}=0.000$ ). This indicates that lecturers' satisfaction has a significant influence on the actual usage of the Sakai LMS. However, lecturers' satisfaction did not influence intention to use $(\beta=0.154, \mathrm{P}=$ $0.115)$. Lastly, hypothesis $\mathrm{H} 6 \mathrm{a}$ was positive and significant $(\beta=0.500, \mathrm{P}=0.000)$. 


\begin{tabular}{|c|c|c|c|c|}
\hline Hypothesis & Coefficient (Beta) & T statistics & $P$ values & Decision \\
\hline H1a: SQ $\rightarrow$ LS & 0.078 & 1.046 & 0.296 & Not supported \\
\hline $\mathrm{H} 1 \mathrm{~b}: \widetilde{\mathrm{SQ}} \rightarrow \mathrm{IU}$ & 0.259 & 3.016 & $0.003^{* * *}$ & supported \\
\hline $\mathrm{H} 1 \mathrm{c}: \mathrm{SQ} \rightarrow \mathrm{PU}$ & 0.688 & 15.332 & $0.000^{* * *}$ & supported \\
\hline H2a: $\widetilde{P U} \rightarrow \mathrm{IU}$ & 0.248 & 2.674 & $0.008 * * *$ & supported \\
\hline H3a: SerQ $\rightarrow$ LS & 0.429 & 5.406 & $0.000^{* * *}$ & supported \\
\hline H3b: SerQ $\rightarrow$ IU & 0.277 & 2.972 & $0.003 * * *$ & supported \\
\hline H4a: $\mathrm{Q} \rightarrow \widetilde{L S}$ & 0.403 & 5.134 & $0.000^{* * *}$ & supported \\
\hline H4b: IQ $\rightarrow$ IU & -0.048 & 0.582 & 0.561 & Not supported \\
\hline H5a: $\widetilde{L S} \rightarrow \mathrm{AU}$ & 0.332 & 4.070 & $0.000^{* * *} *$ & supported \\
\hline H5b: LS $\rightarrow$ IU & 0.154 & 1.580 & 0.115 & Not supported \\
\hline H6a: IU $\rightarrow$ AU & 0.500 & 6.367 & $0.000^{* * *}$ & supported \\
\hline
\end{tabular}

\section{DISCUSSION}

This study intended to determine key factors responsible for the adoption of Sakai LMS among university lecturers. Sakai is a type of e-learning system used by lecturers' of a Ghanaian government university. Although the university has been using Sakai LMS to support teaching and learning for several years now, its continued usage is determined by learners' adoption, satisfaction and actual usage. In an attempt to explain the lecturers' adoption of Sakai LMS, seven factors were selected. Among the variables, the study found system quality as a strong predictor of perceived usefulness with the e-learning system, contributing to $68.8 \%$ of the variance. This finding suggests that if the e-learning system is stable, secure, easy to use, fast and very responsive, lecturers' will find it generally good and perceive it as something useful. This is consistent with similar studies (Cheng et al., 2012; Kim and Lee, 2014). Besides, system quality was also found to have a positive effect on the intention to use Sakai LMS, contributing to $25.9 \%$ of variances. This designates that lecturers' intention to use Sakai LMS is influenced by the availability of the system, reliability, response time, security and how the system can help them carry out the basic task and as well as the design functionality of the system. This result is in accord with studies such as those in Wang and Chiu (2011) and Mtebe and Raphael (2018). However, system quality had no significant effect on lecturers' satisfaction. This finding supports other research works such as Yakubu and Dasuki (2018); Lwoga (2014) and Mohammadi (2015). The non-significant relationship between system quality and lecturers' satisfaction is that lecturers' satisfaction may not necessarily be based on the quality of the system, rather, a factor like poor internet and network access may have led to their dissatisfaction. Nevertheless, this finding opposes other studies, like Saba (2013) and Wang and Chiu (2011) who found system quality to have a positive effect on users' satisfaction. Service quality was hypothesized to significantly influence lecturers' satisfaction and intention to use. Service quality with the relationship with lecturers' satisfaction was found to be statistically significant, contributing to $42.9 \%$ of the variances. It is realized that when there is the provision of both IT support services (response, technical knowledge, etc.) and IT resource service (computers, internet, network equipment, etc.) to lecturers, it can potentially increase their satisfaction with e-learning systems. This finding supports the works of Xu et al. (2014); Poulova and Simonova (2014); and Tajuddin et al. (2013).

Further, the relationship between service quality and intention to use was also found to be significant. These findings could indicate that if an e-learning system can provide different types of services needed by users, it will increase their intention to adopt. This is consistent with other studies (e.g. (Cheng, 2012; Li et al., 2012)). The D\&M IS success model proposes that information quality influences both intentions to use and User Satisfaction. In this study, the results show that information quality was statistically significant to lecturers' satisfaction. This finding corroborates other studies (e.g. (Hassanzadeh et al., 2012; Kim et al., 2012; Saba, 2013)). This implies that lecturers' are satisfied with the feedback generated by the system. The non-significant relationship between information 
quality and intention to use may cater for the reason that the information provided by the system developers may not be too clear to understand and may not be well presented. This is contrary to prior studies (Hassanzadeh et al., 2012; Yakubu and Dasuki, 2018). Lecturers' satisfaction and actual use (system usage) were also found to be statistically significant. This finding is also in support of the work of Hassanzadeh et al. (2012). However, there was no support for lecturers' satisfaction and intention to use e-learning. This result conflicts with other studies like Petter et al. (2008). Perhaps the reason for the insignificant relationship between lecturers' satisfaction and intention to use could be attributed to poor network services. Finally, intention to use and actual usage was found to be statistically significant. This finding supports the work of Chow et al. (2012) and Hassanzadeh et al. (2012).

\section{CONCLUSION}

This study assessed the adoption of e-learning by lecturers in Ghanaian universities by integrating the Technology Acceptance Model (TAM) and the DeLone and McClean IS Success model. Analyzing the 131 respondents this research revealed that systems quality had a positive and a statistically significant influence on lecturer's intention to use Sakai LMS. The findings also showed system quality had a positive influence on lecturers' perceived usefulness with Sakai LMS. However, systems quality did not have a positive and a statistically significant influence on lecturer's satisfaction with Sakai LMS. Perceived usefulness showed a positive influence on lecturers' intention to use Sakai. Furthermore, service quality was seen to have a positive influence on lecturers' satisfaction with Sakai and also with the intention to use Sakai. Regarding information quality, it's interesting to note that it had a positive influence on lecturers' satisfaction with Sakai but did not positively influence their intention to use the Sakai. Likewise, lecturer's satisfaction had a positive influence on the intention to use Sakai LMS but did not have a positive influence on the actual use of Sakai LMS. And finally, the intention to use Sakai LMS had a positive influence on the actual use.

\subsection{Research Implications}

It is realized that developed economies are highly proficient in adopting and using technology to enhance teaching and learning in the classroom as compared to developing economies. It is also found that developing economies are trying its best to catch up in the adoption stage. In a developing country like Ghana, it seems most of the higher education institutions still lack technology implementation and usage in the classroom. Inadequate resources and infrastructure may be considered as one of the problems facing some these institutions to implement educational technology. The existence of cultural differences between developed and developing countries means it is necessary to investigate the factors contributing to the use of eLearning applications. It is understood that the level of technology adoption in developed countries may not be the same as that of developing countries. Hence, there is more room for academic research to explore the different rate of adoption. The findings of this study have significant practical and theoretical implications for the adoption of eLearning in developing countries, particularly in Ghana. The study will help e-learning system developers, academic instructors and administrators to a critical look at the determinants or factors when deploying e-learning in their institution. Factors such as system quality, service quality, information quality, perceived usefulness all have been seen to have a great influence on user technology adoption. Developers of the e-learning system should critically look at these factors to improve users' adoption. Moreover, the system interfaces must be more user-friendly, and one that requires basic skills in information technology to operate. Sufficient support and training should also be provided to both the students and instructors to improve their adoption of rate. The study, therefore, contributes to the research gap on the lack of elearning studies in developing countries that have emphasized the use of eLearning systems. By empirically 
validating the DeLone and McLean model in a different context, particularly sub-Saharan Africa, the study again contributes to the body of knowledge on e-learning adoption.

\subsection{Limitation of the Research and Suggestion for Future Research}

The first limitation of this research is the sample which comprises of university lecturers in Ghana. Sakai is a software used by both students and lecturers to facilitate distance learning. So, the concentration of the analysis on just lecturers may not give the clearest picture of the adoption of the software. Future research may look into the adoption at both students and lecturers' level. Second, it is unknown how well the model and its analysis may apply to other developing country's tertiary education (i.e. Nigeria, Kenya, South Africa and so on). Research into Sakai LMS adoption in other developing countries will come in handy. Lastly, the computer literacy level of lecturers used for the study may not give accurate findings, hence, future studies ought to assess lecturers' computer skills as a basis for using educational softwares to enhance teaching and learning.

\section{REFERENCES}

Acton, T., R. Halonen, K. Conboy and W. Golden, 2009. DeLone \& McLean success model as a descriptive tool in evaluating the use of a virtual learning environment.

Ajzen, I., 1991. The theory of planned behavior. Organizational Behavior and Human Decision Processes, 50(2): $179-211$.

Al-Harbi, K.A.-S., 2011. E-Learning in the Saudi tertiary education: Potential and challenges. Applied Computing and Informatics, 9(1): 31-46.Available at: https://doi.org/10.1016/j.aci.2010.03.002.

Alalwan, A.A., A.M. Baabdullah, N.P. Rana, K. Tamilmani and Y.K. Dwivedi, 2018. Examining adoption of mobile internet in Saudi Arabia: Extending TAM with perceived enjoyment, innovativeness and trust. Technology in Society, 55: 100110.Available at: https://doi.org/10.1016/j.techsoc.2018.06.007.

Alkhalaf, S., S. Drew, R. Alghamdi and O. Alfarraj, 2012. E-learning system on higher education institutions in KSA: Attitudes and perceptions of faculty members. Procedia-Social and Behavioral Sciences, 47: 1199-1205.Available at: https://doi.org/10.1016/j.sbspro.2012.06.800.

Alsabawy, A.Y., A. Cater-Steel and J. Soar, 2013. IT infrastructure services as a requirement for e-learning system success. Computers \& Education, 69: 431-451.Available at: https://doi.org/10.1016/j.compedu.2013.07.035.

Bagozzi, R.P. and Y. Yi, 1988. On the evaluation of structural equation models. Journal of the Academy of Marketing Science, $16(1): 74-94$.

Balash, F., Z. Yong and B. Bin Abu, 2011. Lecturers and educational technology: Factors affecting educational technology adoption in teaching. 2nd International Conference on Education and Management Technology IPCSIT, 13.

Bidin, S. and A.A. Ziden, 2013. Adoption and application of mobile learning in the education industry. Procedia-Social and Behavioral Sciences, 90: 720-729.Available at: https://doi.org/10.1016/j.sbspro.2013.07.145.

Boyi, A.A., 2014. Education and sustainable national development in Nigeria: Challenges and way forward. International Letters of Social and Humanistic Sciences, 14: 65-72.Available at: https://doi.org/10.18052/www.scipress.com/ilshs.14.65.

Burton-Jones, A. and G.S. Hubona, 2006. The mediation of external variables in the technology acceptance model. Information \& Management, 43(6): 706-717.Available at: https://doi.org/10.1016/j.im.2006.03.007.

Chen, H.-R. and H.-F. Tseng, 2012. Factors that influence acceptance of web-based e-learning systems for the in-service education of junior high school teachers in Taiwan. Evaluation and Program Planning, 35(3): 398-406.Available at: https://doi.org/10.1016/j.evalprogplan.2011.11.007. 
Cheng, B., M. Wang, J. Moormann, B.A. Olaniran and N.-S. Chen, 2012. The effects of organizational learning environment factors on e-learning acceptance. Computers \& Education, 58(3): 885-899.Available at: https://doi.org/10.1016/j.compedu.2011.10.014.

Cheng, Y.-M., 2012. Effects of quality antecedents on e-learning acceptance. Internet Research: Electronic Networking Applications and Policy, 22(3): 361-390.Available at: https://doi.org/10.1108/10662241211235699.

Chong, A.Y.-L., K.-B. Ooi, B. Lin and H. Bao, 2012. An empirical analysis of the determinants of $3 \mathrm{G}$ adoption in China. Computers in Human Behavior, 28(2): 360-369.

Chow, M., D.K. Herold, T.-M. Choo and K. Chan, 2012. Extending the technology acceptance model to explore the intention to use second life for enhancing healthcare education. Computers \& education, 59(4): 1136-1144.Available at: https://doi.org/10.1016/j.compedu.2012.05.011.

Davis, F.D., 1989. Perceived usefulness, perceived ease of use, and user acceptance of information technology. MIS Quarterly, 13(3): 319-339.Available at: https://doi.org/10.2307/249008.

Davis, F.D., R.P. Bagozzi and P.R. Warshaw, 1992. Extrinsic and intrinsic motivation to use computers in the workplace 1. Journal of Applied Social Psychology, 22(14): 1111-1132.

DeLone, W.H. and E.R. McLean, 1992. Information systems success: The quest for the dependent variable. Information Systems Research, 3(1): 60-95.Available at: https://doi.org/10.1287/isre.3.1.60.

Delone, W.H. and E.R. McLean, 2003. The DeLone and McLean model of information systems success: A ten-year update. Journal of Management Information Systems, 19(4): 9-30.Available at: https://doi.org/10.1080/0742 1222.2003.11045748.

Delone, W.H. and E.R. Mclean, 2004. Measuring e-commerce success: Applying the DeLone \& McLean information systems success model. International Journal of Electronic Commerce, 9(1): 31-47.Available at: https://doi.org/10.1080/10864415.2004.11044317.

Duan, Y., Q. He, W. Feng, D. Li and Z. Fu, 2010. A study on e-learning take-up intention from an innovation adoption perspective: A case in China. Computers \& Education, 55(1): 237-246.Available at: https://doi.org/10.1016/j.compedu.2010.01.009.

Dzandu, M.D., H. Boateng, F.G. Agyemang and F. Quansah, 2016. Social media adoption among university students: The role of gender, perceived usefulness and perceived ease of use. International Journal of Social Media and Interactive Learning Environments, 4(2): 24.Available at: https://doi.org/10.1504/ijsmile.2016.077584.

Fornell, C. and D.F. Larcker, 1981. Evaluating structural equation models with unobservable variables and measurement error. Journal of Marketing Research, 18(1): 39-50.Available at: https://doi.org/10.1177/002224378101800104.

Frank, K.A., Y. Zhao and K. Borman, 2004. Social capital and the diffusion of innovations within organizations: The case of computer technology in schools. Sociology of Education, 77(2): 148-171.Available at: https://doi.org/10.1177/003804070407700203.

Freeze, R.D., K.A. Alshare, P.L. Lane and H.J. Wen, 2010. IS success model in E-learning context based on students' perceptions. Journal of Information Systems Education, 21(2): 173-184.

Gamble, C., 2017. Exploring EFL university students' acceptance of E-learning using TAM. Kwansei Gakuin. University Humanities Review, 22(2): 23-37.

Gangwar, H., H. Date and R. Ramaswamy, 2015. Understanding determinants of cloud computing adoption using an integrated TAM-TOE model. Journal of Enterprise Information Management, 28(1): 107-130.Available at: https://doi.org/10.1108/jeim-08-2013-0065. 
Gupna, V., D.S. Chauhan and K. Dutta, 2013. Incremental development \& revolutions of e-learning software systems in education sectors: A case study approach. Human-Centric Computing and Information Science, 3(8): 2-14.Available at: https://doi.org/10.1186/2 192-1962-3-8.

Hair, J.F., G.T.M. Hult, C.M. Ringle and M. Sarstedt, 2013. A primer on partial least squares structural equation modeling (PLS-SEM). Thousand Oaks: Sage.

Hair, J.F., T.M. Hult, C.M. Ringle and M. Sarstedt, 2014. A primer on partial least squares structural equation modeling (PLSSEM). Los Angeles, CA: Sage.

Hair, J.F., M. Sarstedt, T.M. Pieper and C.M. Ringle, 2012. The use of partial least squares structural equation modeling in strategic management research: A review of past practices and recommendations for future applications. Long Range Planning, 45(5-6): 320-340.Available at: https://doi.org/10.1016/j.lrp.2012.09.008.

Hassan, M.U., A. Iqbal and Z. Iqbal, 2018. Factors affecting the adoption of internet banking in Pakistan: An integration of technology acceptance model and theory of planned behaviour. International Journal of Business Information Systems, 28(3): 342-370.Available at: https://doi.org/10.1504/ijbis.2018.092530.

Hassanzadeh, A., F. Kanaani and S. Elahi, 2012. A model for measuring e-learning systems success in universities. Expert Systems with Applications, 39(12): 10959-10966.Available at: https://doi.org/10.1016/j.eswa.2012.03.028.

Hsu, M.-H., C.-M. Chang, K.-K. Chu and Y.-J. Lee, 2014. Determinants of repurchase intention in online group-buying: The perspectives of DeLone \& McLean IS success model and trust. Computers in Human Behavior, 36: 234-245.Available at: https://doi.org/10.1016/j.chb.2014.03.065.

Hulland, J., 1999. Use of partial least squares (PLS) in strategic management research: A review of four recent studies. Strategic Management Journal, 20(2): 195-204.Available at: https://doi.org/10.1002/(sici)1097-0266(199902)20:2<195::aid$\operatorname{smj} 13>3.0 . \operatorname{co} ; 2-7$.

Iivari, J., 2005. An empirical test of the DeLone-McLean model of information system success. ACM SIGMIS Database: The Database for Advances in Information Systems, 36(2): 8-27.Available at: https://doi.org/10.1 145/1066149.1066152.

Islam, A., 2012. The role of perceived system quality as educators' motivation to continue e-learning system use. AIS Transactions on Human-Computer Interaction, 4(1): 25-43.Available at: https://doi.org/10.17705/1 thci.00037.

Jagannathan, V., S. Balasubramanian and T. Natarajan, 2018. An extension to the Delone and Mclean information systems success model and validation in the internet banking context. In M. Khosrow-Puour (Ed.), Encyclopedia of Information Science and Technology. 4th Edn., pp: 49-60.

Khasawneh, M., 2015. Factors influence e-learning utilization in Jordanian universities-academic staff perspectives. ProcediaSocial and Behavioral Sciences, 210: 170-180.Available at: https://doi.org/10.1016/j.sbspro.2015.11.356.

Kim, H.-W., H.C. Chan and S. Gupta, 2007. Value-based adoption of mobile internet: An empirical investigation. Decision Support Systems, 43(1): 111-126.Available at: https://doi.org/10.1016/j.dss.2005.05.009.

Kim, K., S. Trimi, H. Park and S. Rhee, 2012. The impact of CMS quality on the outcomes of e-learning systems in higher education: An empirical study. Decision Sciences Journal of Innovative Education, 10(4): 575-587.Available at: https://doi.org/10.1111/j.1540-4609.2012.00360.x.

Kim, Y. and H.S. Lee, 2014. Quality, perceived usefulness, user satisfaction, and intention to use: An empirical study of ubiquitous personal robot service. Asian Social Science, 10(11): 1.Available at: https://doi.org/10.5539/ass.v10n 11 p1.

King, W.R. and J. He, 2006. A meta-analysis of the technology acceptance model. Information \& Management, 43(6): 740755.Available at: https://doi.org/10.1016/j.im.2006.05.003.

Kolodinsky, J.M., J.M. Hogarth and M.A. Hilgert, 2004. The adoption of electronic banking technologies by US consumers. International Journal of Bank Marketing, 22(4): 238-259.Available at: https://doi.org/10.1 108/02652320410542536.

Lee-Post, A., 2009. E-learning success model: An information systems perspective. Electronic Journal of e-learning, 7(1): 61-70. 
Li, Y., Y. Duan, Z. Fu and P. Alford, 2012. An empirical study on behavioural intention to reuse e-learning systems in rural China. British Journal of Educational Technology, 43(6): 933-948.Available at: https://doi.org/10.1111/j.14678535.2011.01261.x.

Lwoga, E.T., 2014. Critical success factors for the adoption of web-based learning management systems in Tanzania. International Journal of Education and Development using Information and Communication Technology, 10(1): 4-21.

McFarland, D.J. and D. Hamilton, 2006. Adding contextual specificity to the technology acceptance model. Computers in Human Behavior, 22(3): 427-447.Available at: https://doi.org/10.1016/j.chb.2004.09.009.

Mohammadi, H., 2015. Investigating users' perspectives on e-learning: An integration of TAM and IS success model. Computers in Human Behavior, 45: 359-374.Available at: https://doi.org/10.1016/j.chb.2014.07.044.

Mtebe, J.S. and C. Raphael, 2018. Key factors in learners' satisfaction with the E-learning system at the university of Dar es Salaam, Tanzania. Australasian Journal of Educational Technology, 34(4): 107-122.Available at: https://doi.org/10.14742/ajet.2993.

Oliveira, T., M. Thomas and M. Espadanal, 2014. Assessing the determinants of cloud computing adoption: An analysis of the manufacturing and services sectors. Information \& Management, 51(5): 497-510.Available at: https://doi.org/10.1016/j.im.2014.03.006.

Opoku, D. and I.N. Adu, 2016. Exploring the determinants of third generation (3G) mobile technology adoption among university students. Journal of Emerging Trends in Computing and Information Sciences, 7(6): 297-310.

Opoku, D., N.I. Adu and G.Y. Koi-Akrofi, 2016. Assessing 3G technology deployment in the telecommunication industry in Ghana: An application of Porter's five-forces competitive framework. ARPN Journal of Science and Technology, 7(7): 319-327.

Ozdamli, F. and H. Uzunboylu, 2014. M-learning and perceptions of students and teachers in secondary schools. British Journal of Educational Technology, 46(1): 159-172.

Petit, D.D.O., H. Wharrad and R. Windle, 2013. Exploring the underlying factors influencing e-learning adoption in nurse education. Journal of Advanced Nursing, 69(6): 1289-1300.Available at: https://doi.org/10.1111/j.13652648.2012.06120.x.

Petter, S., W. DeLone and E. McLean, 2008. Measuring information systems success: Models, dimensions, measures, and interrelationships. European Journal of Information Systems, 17(3): 236-263.Available at: https://doi.org/10.1057/ejis.2008.15.

Pobee, F. and D. Opoku, 2018. The moderating effects of gender on e-commerce systems adoption factors. International Journal of Strategic Decision Sciences (IJSDS), 9(4): 86-104.Available at: https://doi.org/10.4018/ijsds.2018100106.

Poulova, P. and I. Simonova, 2014. E-learning reflected in research studies in Czech Republic: Comparative analyses. ProcediaSocial and Behavioral Sciences, 116: 1298-1304.Available at: https://doi.org/10.1016/j.sbspro.2014.01.386.

Ramayah, T., N.H. Ahmad and M.-C. Lo, 2010. The role of quality factors in intention to continue using an e-learning system in Malaysia. Procedia-Social and Behavioral Sciences, 2(2): 5422-5426.Available at: https://doi.org/10.1016/j.sbspro.2010.03.885.

Roca, J.C., C.-M. Chiu and F.J. Martínez, 2006. Understanding e-learning continuance intention: An extension of the technology acceptance model. International Journal of human-computer studies, 64(8): 683-696.

Ruiz, J.G., M.J. Mintzer and R.M. Leipzig, 2006. The impact of e-learning in medical education. Academic Medicine, 81(3): 207212.

Saade, R., F. Nebebe and W. Tan, 2007. Viability of the" technology acceptance model" in multimedia learning environments: A comparative study. Interdisciplinary Journal of E-Learning and Learning Objects, 3(1): 175-184. 
Saba, T., 2013. Implications of e-learning systems and self-efficacy on students' outcomes: A model approach. Human-Centric Computing and Information Science, 2(6): 2-11.

Sanchez-Franco, M.J., 2009. The moderating effects of involvement on the relationships between satisfaction, trust and commitment in e-banking. Journal of Interactive Marketing, 23(3): 247-258.Available at: https://doi.org/10.1016/j.intmar.2009.04.007.

Sawang, S., C. Newton and K. Jamieson, 2013. Increasing learners' satisfaction/intention to adopt more e-learning. Education and Training, 55(1): 83-105.Available at: https://doi.org/10.1108/00400911311295031.

Schierz, P.G., O. Schilke and B.W. Wirtz, 2010. Understanding consumer acceptance of mobile payment services: An empirical analysis. Electronic Commerce Research and Applications, 9(3): 209-216.Available at: https://doi.org/10.1016/j.elerap.2009.07.005.

Seddon, P. and M.-Y. Kiew, 1996. A partial test and development of DeLone and McLean's model of IS success. Australasian Journal of Information Systems, 4(1): 90-109.Available at: https://doi.org/10.3127/ajis.v4i1.379.

Selim, H.M., 2007. Critical success factors for e-learning acceptance: Confirmatory factor models. Computers \& Education, 49(2): 396-413.Available at: https://doi.org/10.1016/j.compedu.2005.09.004.

Sharma, S.K., A.H. Al-Badi, S.M. Govindaluri and M.H. Al-Kharusi, 2016. Predicting motivators of cloud computing adoption: A developing country perspective. Computers in Human Behavior, 62: 61-69.Available at: https://doi.org/10.1016/j.chb.2016.03.073.

Shraim, K. and Z. Khlaif, 2010. An e-learning approach to secondary education in Palestine: Opportunities and challenges. Information Technology for Development, 16(3): 159-173.Available at: https://doi.org/10.1080/02681102.2010.501782.

Solangi, Z.A., F. Al Shahrani and S.M. Pandhiani, 2018. Factors affecting successful implementation of eLearning: Study of colleges and institutes sector RCJ Saudi Arabia. International Journal of Emerging Technologies in Learning, 13(06): 223-230.Available at: https://doi.org/10.3991/ijet.v13io6.8537.

Suki, N.M., 2011. Subscribersâ€ $€^{\mathrm{TM}}$ intention towards using 3G mobile services. Journal of Economics and Behavioral Studies, 2(2): 67-75.

Tajuddin, R.A., M. Baharudin and T.S. Hoon, 2013. System quality and its influence on students' learning satisfaction in UiTM Shah Alam. Procedia-Social and Behavioral Sciences, 90: 677-685.Available at: https://doi.org/10.1016/j.sbspro.2013.07.140.

Tan, P.J.B. and M.-H. Hsu, 2018. Designing a system for English evaluation and teaching devices: A PZB and TAM model analysis. Eurasia Journal of Mathematics, Science and Technology Education, 14(6): 2107-2119.Available at: https://doi.org/10.29333/ejmste/86467.

Udo, G.J., K.K. Bagchi and P.J. Kirs, 2011. Using SERVQUAL to assess the quality of e-learning experience. Computers in Human Behavior, 27(3): 1272-1283.Available at: https://doi.org/10.1016/j.chb.2011.01.009.

Venkatesh, V., M.G. Morris, G.B. Davis and F.D. Davis, 2003. User acceptance of information technology: Toward a unified view. MIS Quarterly, 27(3): 425-478.Available at: https://doi.org/10.2307/30036540.

Wang, H.C. and Y.F. Chiu, 2011. Assessing e-learning 2.0 system success. Computers \& Education, 57(2): 1790-1800.Available at: https://doi.org/10.1016/j.compedu.2011.03.009.

Wang, Y.-S. and Y.-W. Liao, 2008. Assessing eGovernment systems success: A validation of the DeLone and McLean model of information systems success. Government Information Quarterly, 25(4): 717-733.Available at: https://doi.org/10.1016/j.giq.2007.06.002.

WIUS, 2018. Available from http:// www.internetworldstats.com/stats.htm.

World Internet Users' Statistics, 2018. Available from https://www.internetworldstats.com/africa.htm\#gh. 
Xu, D., W.W. Huang, H. Wang and J. Heales, 2014. Enhancing e-learning effectiveness using an intelligent agent-supported personalized virtual learning environment: An empirical investigation. Information \& Management, 51(4): 430440.Available at: https://doi.org/10.1016/j.im.2014.02.009.

Yakubu, M.N. and S. Dasuki, 2018. Assessing eLearning systems success in Nigeria: An application of the DeLone and McLean information systems success model. Journal of Information Technology Education: Research, 17: 183-203.Available at: https://doi.org/10.28945/4077.

Yang, K.C., 2005. Exploring factors affecting the adoption of mobile commerce in Singapore. Telematics and Informatics, 22(3): 257-277.Available at: https://doi.org/10.1016/j.tele.2004.11.003.

Online Science Publishing is not responsible or answerable for any loss, damage or liability, etc. caused in relation to/arising out of the use of the content. Any queries should be directed to the corresponding author of the article. 